\title{
Performance of Nellore males under different artificial shading levels in the feedlot
}

\section{Desempenho de machos Nelore em diferentes níveis de sombreamento artificial em confinamento}

\author{
Diogo Alves da Costa Ferro ${ }^{1 *}$; Emmanuel Arnhold ${ }^{2}$; Claudia Peixoto Bueno ${ }^{1}$; \\ Eliane Sayuri Miyagi²; Rafael Alves da Costa Ferro'; Bruna Paula Alves da Silva ${ }^{3}$
}

\begin{abstract}
The objective of this study was to evaluate the influence of artificial shading on weight gain and meat quality of male Nellore cattle in an intensive production system. The experiment was conducted in the experimental feedlot of the Course of Animal Science at Universidade Estadual de Goiás, from July to October 2014. Forty-eight male Nellore cattle with an average initial weight of $310 \mathrm{~kg}$ were kept in double $24-\mathrm{m}^{2}$ stalls, in a total of 24 stalls. Of these, six were in the open air; six were covered with black shade netting of $30 \%$ light interception; six with black shade netting $50 \%$; and six with black shade netting $80 \%$, providing $6 \mathrm{~m}^{2}$ of shade per stall. The ration supplied to the animals and the orts left in the trough were weighed daily to determine intake, and the temperature-humidity index (THI) was measured twice weekly. Animals were weighed for the first time at the start of the experiment, and then another three times until the end, which was followed by the slaughter and assessments of performance and meat quality. A difference $(p<0.05)$ was observed between the average THI values, with the highest value found in the stalls without artificial shading. No difference $(p>0.05)$ was observed for feed intake, initial weight, final weight, total weight gain, average daily weight gain, carcass yield, marbling, texture, fatness, backfat thickness, loin-eye area, color, thigh length and circumference, leg length and circumference, or carcass length between the animals on the different treatments. The use of artificial shading does not have a significant effect on performance or meat quality of feedlot Nellore cattle when the ambient temperature is within the thermal comfort zone.
\end{abstract}

Key words: Ambience. Carcass. Intensive system. Quality.

\section{Resumo}

Objetivou-se avaliar a influência do sombreamento artificial no ganho em peso e na qualidade da carne de machos bovinos Nelore em sistema intensivo de produção. O experimento foi realizado no confinamento experimental do curso de Zootecnia da Universidade Estadual de Goiás, no período de julho a outubro de 2014. Utilizaram-se 48 bovinos machos Nelore, com peso médio inicial de 310 $\mathrm{kg}$, mantidos em baias duplas de $24 \mathrm{~m}^{2}$, sendo utilizados 24 baias, destas, seis a céu aberto, seis com sombrite preto com malha $30 \%$, seis com malha $50 \%$ e seis com malha $80 \%$, cobrindo seis $\mathrm{m}^{2}$ de sombra por baia. Diariamente era realizada a pesagem da ração fornecida aos animais e das sobras da ração no cocho para determinação do consumo, e duas vezes por semana realizava-se a avaliação de ITU. No

\footnotetext{
${ }^{1}$ Profs. Drs. Titulares, Curso de Zootecnia, Universidade Estadual de Goiás, UEG, São Luís de Montes Belos, GO, Brasil. E-mail: diogo.ferro@ueg.br; vetcpb@gmail.com; rafael.ferro@ueg.br

2 Profs. Drs. Titulares, Escola de Veterinária e Zootecnia, Universidade Federal de Goiás, UFG, Goiânia, GO, Brasil. E-mail: emmanuelarnhold@yahoo.com.br; eliane.miyagi@gmail.com

3 Prof ${ }^{a}$ M.e, Curso de Zootecnia, UEG, São Luís de Montes Belos, GO, Brasil. E-mail: bruna.silva@ueg.br

* Author for correpondence
} 
inicio do experimento foi realizado a pesagem inicial dos animais e outras três pesagem até o final do experimento, seguido do abate e avaliações de desempenho e qualidade da carne. Observou-se diferença $(\mathrm{p}<0,05)$ entre os valores médios de ITU, sendo o de maior índice as baias sem sombreamento artificial. Não houve diferença $(\mathrm{p}>0,05)$ entre o consumo de ração, peso inicial, peso final, ganho em peso total, ganho em peso médio diário, rendimento de carcaça, marmoreio, textura, acabamento, espessura de gordura subcutânea, área de olho de lombo, coloração, comprimento e perímetro de coxa, comprimento e perímetro de braço e comprimento de carcaça dos animais nos diferentes tratamentos. Conclui-se que a utilização de sombreamento artificial não tem efeito significativo no desempenho e na qualidade da carne de bovinos Nelore em confinamento quando a temperatura ambiente estiver dentro da zona de conforto térmico.

Palavras-chave: Ambiência. Carcaça. Qualidade. Sistema intensivo.

\section{Introduction}

The Brazilian meat production system has been developing every year, with animals raised either exclusively on pasture, or finished in the feedlot. However, producing meat in quantity and quality requires the use of balanced diets, the choice of animals best suited to certain regions, and the adoption of facilities that can provide greater welfare and responses from animals.

According to Bianchini et al. (2007), most of the animals raised in Brazil for meat production are Bos indicus, recognized for their capacity to adapt to climatic conditions of the country such as high temperatures. The adaptation capacity of the Nellore is highly associated with their hair color, epidermal pigmentation, and quantity and volume of sweat glands.

Despite the high resistance of these animals to high temperatures, there are regions of the country where temperatures can be higher than the maximum limit supported by the Nellore breed, which, according to Ferreira (2005) is $35^{\circ} \mathrm{C}$. When above the ideal, according to Sousa Júnior et al. (2008), this climatic element may have negative impacts on health, productivity, and well-being, resulting in weight loss, delayed growth, hormonal problems, decreased feed intake, among others.

The animal performance is also determined by the intake of nutrients, their digestibility, and metabolism, which are related to the dry matter intake, which in turn can be greatly influenced by climatic elements (FURTADO et al., 2012). As the ambient temperature is increased, dry matter intake is reduced to reduce the heat increment and control body temperature, since the animal will be more prone to heat stress. As a consequence of the decreased intake, weight gain may be reduced and the meat quality may be altered.

According to Costa-e-Silva et al. (2010), this reduction in weight gain and meat quality may be a result of the physiological and behavioral changes triggered by the animal as a number of non-specific adaptive reactions when it is kept in an inappropriate environment.

The influence of shading on the productive performance of cattle has been widely discussed, but only referring to European or crossbred animals, with few studies available on zebu animals, especially those of the Nellore breed. Thus, the objective of the present study was to evaluate the influence of artificial shading levels on weight gain and meat quality of male Nellore cattle in the feedlot.

\section{Material and Methods}

The experiment was conducted on Escola Farm, at Universidade Estadual de Goiás, on São Luís de Montes Belos Campus (50²2’48' W longitude and $16^{\circ} 31^{\prime} 20^{\prime}$ S latitude). The experiment lasted 86 days, from July to October 2014, authorized by the Ethics Committee on the Use of Animals (Comissão de Ética no Uso de Animais - CEUA) of the UFG, under protocol no. 030/14. 
Forty-eight uncastrated male Nellore animals with an average initial weight of $310 \mathrm{~kg}$ (varying from 306.75 to $314.33 \mathrm{~kg}$ ), at an average age of 20 months, originating from the same commercial herd, were used in the experiment. Animals were kept in the feedlot, in double stalls, in the NorthSouth direction, measuring four meters in width and six meters in length, totaling $24 \mathrm{~m}^{2}$. Twentyfour stalls were used in the total: six in the open air with $0 \%$ shading, six covered with a black shade net made of synthetic polypropylene fiber, 30\%-light interception mesh; six with 50\% light interception; and six with $80 \%$ light interception, covering part of the area, with $6 \mathrm{~m}^{2}$ of shade per stall, distributed continuously.

The ration consisted of silages of sorghum and corn, ground corn, soybean meal, soybean hulls, livestock urea, a mineral-vitamin mix, plus mineral supplementation ad libitum (Table 1). The feeding management was performed four times daily, at $06.00,10.00,13.00$, and $17.00 \mathrm{~h}$, with an average roughage:concentrate ratio of 40:60. The amount provided per animal/treatment was weighed every day, and orts were weighed before the first treatment of the day to calculate the total intake. Diets were formulated using the NRC software.

Table 1. Dietary management of Nellore cattle during the experimental period.

\begin{tabular}{lcccccc}
\hline & 1st stage & 2nd stage & 3rd stage & 4th stage & 5th stage & 6th stage \\
\hline Days of supply & 7 & 7 & 20 & 20 & 20 & 12 \\
\hline Ingredient & 14.000 & 15.000 & 12.000 & 10.000 & 9.000 & 8.500 \\
\hline Silage & 1.600 & 2.100 & 5.000 & 6.500 & 7.500 & 8.300 \\
Ground corn & 0.600 & 0.600 & 0.600 & 0.550 & 0.450 & 0.300 \\
Soybean meal & 0.300 & 0.400 & 1.600 & 1.800 & 2.100 & 2.200 \\
Soybean hulls & 0.070 & 0.080 & 0.110 & 0.125 & 0.130 & 0.145 \\
Urea & 0.120 & 0.130 & 0.220 & 0.230 & 0.240 & 0.250 \\
Mineral mix & 16.690 & 18.310 & 19.530 & 19.205 & 19.420 & 19.695 \\
\hline TOTAL & & & & &
\end{tabular}

Ambient temperature and relative humidity of the air were measured twice weekly using thermohygrometers installed in a central stall in each treatment. These data were measured three times on the previously defined days, at $08.00,13.00$, and $18.00 \mathrm{~h}$. Wind speed was also measured, in $\mathrm{km} / \mathrm{h}$, using a portable digital anemometer.

Dry (DBT) and wet (WBT) bulb thermometer temperatures were collected using psychrometers to determine the temperature-humidity index (THI). According to the methodology proposed by Santos et al. (2013), the THI was calculated by the following formula: $\mathrm{THI}=\mathrm{DBT}+0.36 \times$ $\mathrm{WBT}+41.5$. Collections and determinations took place on the same days and at the same times when temperature and relative air humidity were measured.

On the first day in the feedlot, the animals were weighed for determining the initial weight (IW). Animals were weighed another three times, at 25, 60 , and 86 days of confinement, using a digital scale installed near the exit of the restraint chute. Final weight (FW), total weight gain (TWG), and average daily weight gain (ADWG) were obtained at the end of the experiment.

At 86 days of confinement, the animals were fasted for $16 \mathrm{~h}$, weighed, and transported to an abattoir in Sanclerlândia, GO under State inspection service for the slaughtering procedures. The slaughter was performed according to the current 
legal procedures (RIISPOA). At slaughter, the right and left half-carcasses were identified with signs containing the number of the earring.

After slaughter, carcasses were weighed and the hot carcass weight (HCW) was thus obtained for the calculation of the carcass dressing percentage, using the fasted weight and the HCW (ROTTA et al., 2010).

After all the slaughter procedures were completed, carcasses were stored in a cold room $\left(4{ }^{\circ} \mathrm{C}\right)$ for 24 $h$, and at the end of this period, measurements of carcass length, thigh length and circumference, leg length and circumference, conformation, fatness, loin-eye area, backfat thickness, marbling, texture, and color were taken. All evaluations were performed on the left half-carcass.

On the left half cold carcass, measurements of the metric characteristics of carcass length and length and circumference of the leg and thigh were obtained. The carcass length was determined with a measuring tape, by measuring the cranial border of the ischial pubic symphysis up to the medial cranial border of the first rib. Leg length was measured between the olecranon tuberosity and the radiocarpal joint; leg circumference was obtained in the middle portion of the leg, surrounding it by a tape measure. Thigh length, in turn, was obtained as the distance between the anterior edge of the pubic bone and a mid-point on the tarsal joint bones; thigh circumference was measured in the middle of the thigh, surrounding it by a tape measure.

Conformation, fatness, and texture were evaluated subjectively. To evaluate the conformation, carcasses were categorized as convex, sub-convex, straight, sub-concave, and concave (MOREIRA et al., 2012).

Fatness was assessed visually based on the deposition of fat on the 6th, 9th, and 12th ribs, classified as lean (1) - no fat; sparse fat (2) - 1 to 3 mm thickness; medium fat (3) - 3 to 6 m thickness; uniform fat (4) - 6 to $10 \mathrm{~mm}$ thickness (5); and excess fat (5) - above $10 \mathrm{~mm}$ thickness (VAZ et al., 2012).
After the abovementioned assessments, a section was made between the 12th and 13th ribs, exposing the longissimus dorsi muscle, and a $2.5-\mathrm{cm}$ steak was collected for evaluation of marbling, texture, loin-eye area, and backfat thickness. Marbling was evaluated by counting the marbling traces and subsequent classification based on the methodology proposed by Müller (1980).

To evaluate the texture, a scoring system was adopted that ranged from 1 to 5 , in which 1 indicated very coarse texture; 2 , coarse; 3 , slightly coarse; 4, fine; and 5, very fine (MÜLLER, 1980). Loineye area was determined using tracing paper, by outlining the LEA and superposing it on a planimeter to count the encompassed points, with each point corresponding to a $1.0 \mathrm{~cm}^{2}$ area, this variable was obtained in $\mathrm{cm}^{2}$. Backfat thickness (BFT) was measured using a caliper on the longissimus dorsi steak. The tissue depth was measured at a distance of $3 / 4$ from the medial side of the muscle to its lateral side.

A colorimeter was used in the evaluation of color, determined in the hindquarter region and sirloin, by the $\mathrm{L}^{*}, \mathrm{a}^{*}$, and $\mathrm{b}^{*}$ components. $\mathrm{L}^{*}$ determined the lightness of the sample, ranging from 0 to 100 , with 0 meaning full black, and 100, full white; a+ indicated color tendency towards red; a-, tendency towards green; $\mathrm{b}+$, tendency towards yellow; and b-, tendency towards blue (ROSSATO et al., 2010).

The experiment was conducted as a completely randomized design with four treatments and six replications. With the environmental variables and animal production responses, analysis of variance, F test, and Tukey's test at 5\% for parametric data and Kruskal-Wallis test for non-parametric values were applied using $\mathrm{R}$ computer software (version 2.15.2).

\section{Results and Discussion}

During the experimental period, room temperature reached mean daily minimum 
and maximum values of $16.8{ }^{\circ} \mathrm{C}$ and $39.9{ }^{\circ} \mathrm{C}$, respectively, with an average temperature of $31.8{ }^{\circ} \mathrm{C}$. Air relative humidity and wind speed averaged $43 \%$ and $4.8 \mathrm{~km} / \mathrm{h}$, respectively. In each treatment, the THI were determined, as shown in Table 2.

Table 2. Temperature-humidity index (THI), temperature, and air relative humidity in the stalls without shading and with shade nets of $30 \%, 50 \%$, and $80 \%$ light interception.

\begin{tabular}{lcccccc}
\hline \multirow{2}{*}{ Variable } & \multicolumn{9}{c}{ Shading level $(\%)^{1}$} & \multirow{2}{*}{ P } & \multirow{2}{*}{ CV, \% } \\
\cline { 2 - 5 } & 0 & 30 & 50 & 80 & & 0.035 \\
THI & $80 \mathrm{~b}$ & $82 \mathrm{a}$ & $79 \mathrm{c}$ & $78 \mathrm{~d}$ & & 6.07 \\
Temperature & 32.2 & 32.5 & 31.7 & 30.8 & 0.097 & 9.13 \\
Humidity & 42.7 & 42.5 & 43.2 & 43.6 & 0.387 & 8.93 \\
\hline
\end{tabular}

$\mathrm{P}$ - probability value of the $\mathrm{F}$ test in the analysis of variance; $\mathrm{CV}$ - coefficient of variation.

${ }^{1}$ Variables followed by different letters in the same row differ at 5\% significance level by Tukey's test.

Despite the difference between the THI values, animals were not found to be under stress in most of the days, since the average ambient temperature was $31.8{ }^{\circ} \mathrm{C}$, and according to Ferreira (2005), for adult Nellore cattle to be under heat stress, the ambient temperature must exceed $35^{\circ} \mathrm{C}$. Once under stress, the animals can make use of physiological and behavioral mechanisms to help in body heat dissipation.
No differences were observed $(\mathrm{p}>0.05)$ between the average daily feed intake for the animals kept in stalls with and without access to the different shading levels. When the IW and FW of the animals were evaluated, there was no difference $(p>0.05)$ between the weights in the different treatments. This lack of difference could also be observed for average TWG and ADWG, as shown in Table 3.

Table 3. Performance variables of male Nellore cattle without access to shade and with access to shade nets of $30 \%$, $50 \%$, and $80 \%$ light interception.

\begin{tabular}{|c|c|c|c|c|c|c|}
\hline \multirow{2}{*}{ Variable } & \multicolumn{4}{|c|}{ Shading level (\%) } & \multirow{2}{*}{$\mathrm{P}$} & \multirow{2}{*}{$\mathrm{CV}, \%$} \\
\hline & 0 & 30 & 50 & 80 & & \\
\hline ADI (kg) & 18.92 & 18.71 & 18.87 & 18.82 & 0.8292 & 2.19 \\
\hline IW (kg) & 306.75 & 311.42 & 309.08 & 314.33 & 0.8896 & 13.67 \\
\hline FW (kg) & 459.33 & 456.92 & 453.75 & 464.17 & 0.8576 & 12.42 \\
\hline TWG (kg) & 152.58 & 145.50 & 144.67 & 149.84 & 0.8641 & 12.07 \\
\hline ADWG $(\mathrm{kg})$ & 1.77 & 1.69 & 1.68 & 1.74 & 0.8257 & 12.26 \\
\hline $\mathrm{CD}(\%)$ & 53.00 & 54.43 & 53.47 & 53.42 & 0.0754 & 1.69 \\
\hline
\end{tabular}

ADI - average daily intake, IW - initial weight; FW - final weight; TWG - total weight gain; ADWG - average daily weight gain; $\mathrm{CD}$ - carcass dressing percentage.

$\mathrm{P}$ - probability value of the $\mathrm{F}$ test in the analysis of variance; $\mathrm{CV}$ - coefficient of variation.

Comparing the ADWG and FW of young $1 / 2$ Nellore-Charolais bulls without and with access to shade, using shading net with $70 \%$ light interception, Marques et al. (2007) also did not 
observe differences, obtaining an ADWG of $1.2 \mathrm{~kg}$ in both treatments and FW of 452.0 and $444.5 \mathrm{~kg}$ for the animals with and without access to shade, respectively.

Lopes (2010) evaluated the influence of shading using synthetic polypropylene fiber with $80 \%$ light interception on the ADWG of Nellore and Nellore crossbred cattle in the feedlot receiving a diet composed of sorghum silage, soybean meal, urea, grain sorghum, cottonseed meal, and a mineral mixture, and observed that the animals with access to shade showed differences $(p<0.05)$, gaining more weight (1.35 kg/day) compared with those exposed to the sun $(1.18 \mathrm{~kg} /$ day $)$. This difference was also observed for carcass dressing percentage, whose values were $53.46 \%$ and $53.13 \%$ for the animals with and without access to shade, respectively, due to the reduction of heat stress.
Corroborating the results found by Lopes (2010), no significant differences were found in the present experiment for carcass dressing percentage, with animals showing $53.00 \pm 0.91 \%, 54.43 \pm 0.91 \%$, $53.47 \pm 0.91 \%$, and $53.42 \pm 0.91 \%$ in the treatments without shade and shaded with nets of $30 \%, 50 \%$, and $80 \%$ light interception, respectively.

In the evaluation of the carcass characteristics, it was found that $100 \%$ of the animals had carcass conformation classified as straight. This agrees with Sartor Neto et al. (2011), who evaluated male Nellore cattle confined with an average initial weight of $317.70 \mathrm{~kg}$ and average final weight of $485.88 \mathrm{~kg}$ and observed that the carcass of the animals was classified as straight, which can be characterized as a normal characteristic for carcasses of Nellore animals.

No significant differences were found between the treatments for marbling, texture, fatness, backfat thickness, or loin-eye area (Table 4).

Table 4. Marbling, texture, fatness, backfat thickness (BFT), and loin-eye area (LEA) of male Nellore without access to shade and with access to shade nets of $30 \%, 50 \%$, and $80 \%$ light interception.

\begin{tabular}{|c|c|c|c|c|c|c|}
\hline \multirow{2}{*}{ Variable } & \multicolumn{4}{|c|}{ Shading level (\%) } & \multirow{2}{*}{$\mathrm{P}$} & \multirow{2}{*}{$\mathrm{CV}, \%$} \\
\hline & 0 & 30 & 50 & 80 & & \\
\hline Marbling & 5.50 & 6.33 & 6.17 & 6.50 & 0.4153 & 17.53 \\
\hline Texture & $3.5(3.5)$ & $3.17(3)$ & $3.67(3.5)$ & $3.5(3.5)$ & $0.7425^{*}$ & 7.87 \\
\hline Fatness & $2.33(2)$ & $2.19(2)$ & $2.33(2)$ & $2.66(3)$ & $0.3508^{*}$ & 7.64 \\
\hline BFT (mm) & 4.55 & 4.42 & 5.17 & 4.80 & 0.4815 & 18.47 \\
\hline $\operatorname{LEA}\left(\mathrm{cm}^{2}\right)$ & 86.00 & 84.33 & 87.00 & 89.67 & 0.6713 & 8.72 \\
\hline
\end{tabular}

$\mathrm{P}$ - probability value of the $\mathrm{F}$ test in the analysis of variance; $\mathrm{CV}$ - coefficient of variation.

* Kruskal-Wallis' non-parametric test with mean and median values.

Marbling was evaluated by counting marbling traces. In all treatments, marbling was scored as light, with the unshaded treatment as L0, and the others as L+. According to Müller (1980), marbling can be classified as traces, from 1 to 10 , as follows: $\mathrm{T}-(1)$, T0 (2), and $\mathrm{T}+(3)$; from 4 to 6 , considered light, with L- (4), L0 (5), and L+ (6); 7 to 9, small (S); 10 to 12 , medium (Me); 13 to 15 , moderate (Mo); and 16 to 18 , abundant (A).
Texture was classified as slightly coarse to fine, and fatness, as sparse fat, similar values were found by Vaz et al. (2013) in carcasses of Nellore animals at the same age, reared in an intensive production system, which had texture and fatness values of 3.50 and 2.67 , respectively.

When the average BFT was evaluated in the animals kept in the unshaded stalls and in those covered with shading nets of $30 \%, 50 \%$, and $80 \%$ 
light interception, no difference was detected ( $>0.05)$ between treatments. The BFT found in all treatments is considered good for sale, which in Brazil should be between three and six millimeters (ROTTA et al., 2010), thus contributing to the visual aspect of the carcass and to the meat quality, besides serving as a protection against darkening, dehydration, and shortening of the fibers due to cold during the chilling process, which negatively affects the meat tenderness.

There was no significant difference for LEA, for the animals kept in the stall without shading, and in those shaded by nets of $30 \%, 50 \%$, and $80 \%$ light interception, respectively. According to
Lopes et al. (2012), LEA has a high relationship with the growth rate, increasing as the animal increases its meat deposition in the carcass. This explains the lack of significant differences among the LEA of the evaluated animals, since there was no significant difference for ADWG, FW, and $\mathrm{CD}$ among the animals subjected to the different shading levels.

The meat color was determined in the hindquarter region and in the sirloin on the left halfcarcass of the animals. No significant differences were detected between the main color parameters such as red intensity $\left(a^{*}\right)$, yellow intensity $\left(b^{*}\right)$, and lightness $\left(\mathrm{L}^{*}\right)$ (Table 5).

Table 5. Meat color of the hindquarter region (HQ) and sirloin (SL) of male Nellore without access to shade and with access to shade nets of $30 \%, 50 \%$, and $80 \%$ light interception.

\begin{tabular}{|c|c|c|c|c|c|c|c|}
\hline \multirow{2}{*}{ Color } & \multicolumn{4}{|c|}{ Shading level (\%) } & \multirow{2}{*}{$\mathrm{P}$} & \multirow{2}{*}{$\mathrm{SD}$} & \multirow{2}{*}{$\mathrm{CV}, \%$} \\
\hline & 0 & 30 & 50 & 80 & & & \\
\hline$L^{*}-\mathrm{HQ}$ & 28.63 & 27.67 & 28.08 & 28.55 & 0.8403 & 2.08 & 7.37 \\
\hline $\mathrm{a}^{*}-\mathrm{HQ}$ & 18.07 & 13.83 & 15.30 & 16.12 & 0.1605 & 3.13 & 19.77 \\
\hline $\mathrm{b}^{*}-\mathrm{HQ}$ & 7.85 & 4.20 & 5.88 & 5.93 & 0.1375 & 2.54 & 22.64 \\
\hline$L^{*}-\mathrm{SL}$ & 32.28 & 31.87 & 34.10 & 32.35 & 0.3928 & 2.37 & 7.25 \\
\hline$a^{*}-S L$ & 12.57 & 12.07 & 12.38 & 13.1 & 0.7393 & 1.63 & 13.03 \\
\hline$b^{*}-S L$ & 5.60 & 5.20 & 6.32 & 5.87 & 0.2761 & 0.97 & 16.98 \\
\hline
\end{tabular}

$\mathrm{P}$ - probability value of the $\mathrm{F}$ test in the analysis of variance; $\mathrm{SD}$ - standard deviation; $\mathrm{CV}$ - coefficient of variation.

Evaluating meat color, Muchenjea et al. (2009) described that, in cattle, average lightness ranged from 33.2 to 41.0 , a* between 11.1-23.6, and $b^{*}$ between 6.1-11.3. These values diverged in part from those obtained in the present experiment, corroborating Andrade et al. (2010) and Rossato et al. (2010), who evaluated the meat color of young Nellore animals.
When carcass length, thigh length and circumference, and leg length and circumference were evaluated, no significant differences were detected (Table 6). Very similar values were observed between the lengths and circumferences of the cattle carcasses, which can be explained by the homogeneous ages and weights of these animals. 
Table 6. Body measurements of male Nellore without access to shade and with access to shade nets of $30 \%, 50 \%$, and $80 \%$ light interception.

\begin{tabular}{|c|c|c|c|c|c|c|c|}
\hline \multirow{2}{*}{ Variable } & \multicolumn{4}{|c|}{ Shading level (\%) } & \multirow{2}{*}{$\mathrm{P}$} & \multirow{2}{*}{$\mathrm{SD}$} & \multirow{2}{*}{$\mathrm{CV}, \%$} \\
\hline & 0 & 30 & 50 & 80 & & & \\
\hline CL (m) & 1.45 & 1.47 & 1.48 & 1.47 & 0.5975 & 0.04 & 2.52 \\
\hline TL (m) & 0.76 & 0.78 & 0.78 & 0.76 & 0.1578 & 0.02 & 2.36 \\
\hline $\mathrm{TC}(\mathrm{m})$ & 0.54 & 0.57 & 0.57 & 0.54 & 0.1611 & 0.03 & 6.31 \\
\hline $\mathrm{LL}(\mathrm{m})$ & 0.46 & 0.47 & 0.46 & 0.46 & 0.3732 & 0.01 & 2.54 \\
\hline LC (m) & 0.38 & 0.36 & 0.36 & 0.37 & 0.2840 & 0.02 & 5.86 \\
\hline
\end{tabular}

CL - carcass length; TL - thigh length; TC - thigh circumference; LL - leg length; LC - leg circumference.

$\mathrm{P}$ - probability value of the $\mathrm{F}$ test in the analysis of variance; SD - standard deviation; CV - coefficient of variation.

\section{Conclusions}

Although no difference was observed between performance and carcass and meat characteristics of the animals kept without or with access to shade, artificial shading is recommended as it provides greater comfort, allowing better welfare conditions and quality of life to the animals.

\section{References}

ANDRADE, P. L.; BRESSAN, M. C.; GAMA, L. T.; GONÇAVES, T. M.; LADEIRA, M. M.; RAMOS, E. M. Qualidade da carne maturada de bovinos Red Norte e Nelore. Revista Brasileira de Zootecnia, Viçosa, MG, v. 39, n. 8, p. 1791-1800, 2010.

BIANCHINI, W.; SILVEIRA, A. C.; JORGE, A. M.; ARRIGONI, M. B.; MARTINS, C. L.; RODRIGUES, É.; HADLICH, J. C.; ANDRIGHETTO, C. Efeito do grupo genético sobre as características de carcaça e maciez da carne fresca e maturada de bovinos superprecoces. Revista Brasileira de Zootecnia, Viçosa, MG, v. 36, n. 6, p. 2109-2117, 2007.

COSTA-E-SILVA, E. V.; RUEDA, P. M.; CARNEIRO, R. C. P. B.; MACEDO, G. G.; ZÚCCARI, C. E. S. N. Estratégias para avaliar bem-estar animal em animais em reprodução. Ciências Veterinárias Tropicais, Recife, v. 13, p. 20-28, 2010. Suplemento 1.

FERREIRA, R. A. Maior produção com melhor ambiente para aves, suínos e bovinos. Viçosa, MG: Aprenda Fácil, $2005.371 \mathrm{p}$.

FURTADO, D. A.; PEIXOTO, A. P.; REGIS, J. E. F.; NASCIMENTO, J. W. B.; ARAUJO, T. G. P.; LISBOA,

A. C. C. Termorregulação e desempenho de tourinhos
Sindi e Guzerá, no agreste paraibano. Revista Brasileira de Engenharia Agrícola e Ambiental, Campina Grande, v. 16, n. 9, p. 1022-1028, 2012.

LOPES, A. C. R. Ganho de peso e rendimento de carcaça de bovinos de corte confinados com acesso a sombra. 2010. Dissertação (Mestrado em Ciências Veterinárias) Universidade Federal de Uberlândia, Uberlândia.

LOPES, L. S.; LADEIRA, M. M.; MACHADO NETO, O. R.; PAULINO, V. R.; CHIZZOTTI, M. L.; RAMOS, E. M.; OLIVEIRA, D. M. Características de carcaça e cortes comerciais de tourinhos Red Norte e Nelore terminados em confinamento. Revista Brasileira de Zootecnia, Viçosa, MG, v. 41, n. 4, p. 970-977, 2012.

MARQUES, J. A.; ITO, R. H.; ZAWADZKI, F.; MOGGIONI, D.; BEZERRA, G. A.; PEDROSO, P. H. B.; PRADO, I. N. Comportamento ingestivo de tourinhos confinados com ou sem acesso à sombra. Campo Digital, Campo Mourão, v. 2, n. 1, p. 43-49, jan./jun. 2007.

MOREIRA, P. S. A.; BERBER, R. C. A.; LOURENÇO. F. J.; BELUFI, P. R.; KONRAD, M. Efeito do sexo e da maturidade sobre o peso de carcaça quente, acabamento e conformação de bovinos abatidos em Sinop-MT. Comunicata Scientiae, Bom Jesus, v. 3, n. 4, p. 292-298, 2012.

MUCHENJEA, V.; DZAMAC, B. K.; CHIMONYOA, M.; STRYSOM, P. E.; HUGO, A.; RAATS, J. G. Some biochemical aspects pertaining to beef eating quality and consumer health: a review. Food Chemistry, London, v. 112, n.2, p. 279-289, 2009.

MÜLLER, L. Normas para avaliação de carcaças e concurso de carcaças de novilhos. Santa Maria: UFSM, 1980. $31 \mathrm{p}$.

ROSSATO, L. V.; BRESSAN, M. C.; RODRIGUES, E. C.; GAMA, L. T.; BESSA, R. J. B.; ALVES, S. P. A. Parâmetros físicos-químicos e perfil de ácidos graxos 
da carne de bovinos Angus e Nelore terminados em pastagem. Revista Brasileira de Zootecnia, Viçosa, MG, v. 39, n. 5, p. 1127-1134, 2010.

ROTTA, P. P.; PRADO, I. N.; PRADO, R. M. Desempenho, qualidade da carcaça e da carne em bovinos. In: PRADO, I. N. Produção de bovinos de corte e qualidade da carne. Maringá: Eduem, 2010. 242 p.

SANTOS, A. P. P.; SANTOS, K. J. G.; COSTA, M. A.; FERRO, D. A. C.; FERRO, R. A. C. Bem-estar na bovinocultura relacionado à produção. Pubvet, Londrina, v. 7 , n. 15 , p. 1500-1524, ago. 2013.

SARTOR NETO, A.; RIBEIRO, E. L. A.; MIZUBUTI, I. Y.; PEREIRA, E. S.; CUNHA, G. E.; SILVA, L. D. F.; BARBOSA, M. A. A. F.; BUMBIERIS JUNIOR, V. H. Desempenho e características de carcaça de bovinos Nelore confinados recebendo dietas de alto teor de concentrado com diferentes níveis de tanino. Semina: Ciências Agrárias, Londrina, v. 32, n. 3, p. 1179-1190, 2011.
SOUSA JÚNIOR, S. C.; MORAIS, D. A. E. F.; VASCONCELOS, A. M.; NERY, K. M.; MORAIS, J. H. G.; GUILHERMINO, M. M. Características termorreguladores de caprinos, ovinos e bovinos em diferentes épocas do ano em regiões Semi-Árida. Revista Científica de Produção Animal, Teresina, v. 10, n. 2, p. 127-137, 2008.

VAZ, F. N.; RESTLE, J.; PÁDUA, J. T.; FONSECA, C. A.; PACHECO, P. S. Características de carcaça e receita industrial com cortes primários da carcaça de machos Nelore abatidos com diferentes pesos. Ciência Animal Brasileira, Goiânia, v. 14, n. 2, p. 199-207, 2013.

VAZ, F. N.; VAZ, R. Z.; PASCOAL, L. L.; PACHECO, P. S.; MIOTTO, F. R. C.; TEIXEIRA, N. P. Análise econômica, rendimentos de carcaça e dos cortes comerciais de vacas de descarte 5/8 Hereford 3/8 Nelore abatidas em diferentes graus de acabamento. Ciência Animal Brasileira, Goiânia, v. 13, n. 3, p. 338345, 2012. 
